\title{
Application of the Generalized Method of Moment Arellano-Bond on Economic Growth in Central Java Province in 2011-2018
}

\author{
Maulana Ghani Yusuf ${ }^{1}$, Joko Hadi Susilo ${ }^{2}$, Luthfi Ibnu Tsani ${ }^{3}$ \\ 1,2,3 Magister of Economiccs and Development Studies, Diponegoro University, Semarang, Indonesia
}

\begin{abstract}
This study aims to analyze the effect of the savings rate, population, human development index, and labor force participation rate on economic growth in Central Java Province from 2011 to 2018. This study uses a descriptive quantitative method with dynamic panel regression using the Gereralized Method of Moment Arrelano Bond. The use of this method is intended to determine the effect of each independent and dependent variable in the previous year on the dependent variable in the research year.
\end{abstract}

The results of this study indicate that simultaneously the independent variable has a significant and positive effect on the dependent variable. Then there is an insignificant negative relationship between the saving rate and the population on economic growth. Furthermore, there is an insignificant positive relationship between the development index on economic growth and a significant positive relationship between the level of labor force participation on economic growth.

Keywords:- Economic Growth, Saving Rate, Human Development Index, And Labor Force Participation Rate

\section{INTRODUCTION}

Economic growth according to Sukirno (2011) is defined as an addition to the production of goods and services which has an impact on the level of social welfare. The continuous increase in economic growth shows that the joints of the economy in a country or region are running well. This is because economic growth which always increases every year is the main goal for a government. Todaro and Smith (2004) state that success in economic growth can be shown in three ways, including the ability of the community to meet basic needs, an increase in the feelings that people have as human beings in general and an increase in aspects of human rights.

Economic growth in Indonesia is still quite low if you look at the average of development from year 2000 to 2018, which is 5.27 percent. Even when compared to other countries in ASEAN, Indonesia is ranked 7th out of 10 ASEAN countries. Furthermore, according to Sodik (2007), apart from low economic growth, another problem, namely the impact or effect on the wider community, especially the poor, is still not very pronounced. The low percentage shown regarding the development of economic growth and its low impact on society needs to be considered by the government. One solution that can be done according to Sodik (2007) is by analyzing the influence of regional characteristics. This is because each region has different ways of developing economic growth and community welfare according to the potential and characteristics of each region.

Spatially, the contribution of GDP nationally in 2018 was mostly contributed by all provinces in Java, which amounted to 58 percent compared to other islands. Central Java Province is the province with the lowest average economic growth in Java from 2014 to 2018, namely 5.31 percent as shown in the table below:

\begin{tabular}{|c|c|c|c|c|}
\hline Province & $\mathbf{2 0 1 5}$ & $\mathbf{2 0 1 6}$ & $\mathbf{2 0 1 7}$ & $\mathbf{2 0 1 8}$ \\
\hline DI Yogyakarta & $4,95 \%$ & $5,05 \%$ & $5,26 \%$ & $6,20 \%$ \\
\hline DKI Jakarta & $5,91 \%$ & $5,87 \%$ & $6,20 \%$ & $6,17 \%$ \\
\hline Banten & $5,45 \%$ & $5,28 \%$ & $5,73 \%$ & $5,81 \%$ \\
\hline Jawa Barat & $5,05 \%$ & $5,66 \%$ & $5,35 \%$ & $5,64 \%$ \\
\hline Jawa Timur & $5,44 \%$ & $5,57 \%$ & $5,46 \%$ & $5,50 \%$ \\
\hline Jawa Tengah & $5,47 \%$ & $5,25 \%$ & $5,26 \%$ & $5,32 \%$ \\
\hline
\end{tabular}

Table 1:- Percentage of Economic Growth in Java Island in 2015 - 2018

Source: BPS Central Java Province (2020)

Muana (2001) in his research states that efforts to develop economic growth can be said to be successful if there is an increase in the production of goods and services. This increase can be seen quantitatively using the value of the Gross Regional Domestic Product (GRDP). The value of the GRDP can also be used as a measure of the extent to which the economic development of an area can be used as an evaluation and basis for development planning Hendarto (2012).

Arsyad (2010) in his research states that in the framework of the Harrord - Domar theory of economic growth, the savings or capital factor has a very large role in increasing economic growth in a country. Jhingan (2000) added that a high saving rate will also allow opportunities to increase investment and be able to increase production capacity in the economy. Suhel (2015) states that the saving rate does not only come from natural resource wealth, per capita income, or from the sectoral composition of the Gross Domestic Regional Product (GDRP). However, savings can also come from other factors depending on the several characteristics of the savings mobilization policies that are imposed in each region. When viewed in Figure 1 below, it can be seen that the saving rate owned by the 
Province of Central Java has always increased every year, where the highest increase was from 2016 to 2017.

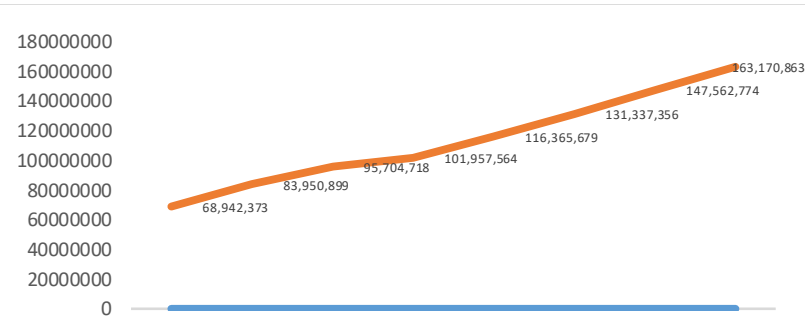

20112012201320142015201620172018

$$
\longrightarrow \text { TAHUN NOMINAL }
$$

Fig 1:- Graph of Central Java Province Savings Position 2011-2018

Source: BPS Central Java Province Processed by Author (2020)

According to classical economic theory, the output produced by a country or region is influenced by population development. Adam Smith in Rochaida (2016) states that classical economic theory is based on the assumption that at that time land was not scarce, capital had not been taken into account, and only focused on working capital. Therefore, population growth is seen as an important factor in boosting economic growth in a country. In Adam Smith's classical economic theory, the concept of the law of diminishing return is not yet applicable. According to him, the ratio between the total population as workers and the amount of land that is cultivated will cause a marginal decline in product so that real wages will also decrease. However, on the other hand, a large population can also be seen as a negative thing because it can reduce job opportunities and increase the unemployment rate of a country due to limited employment opportunities.

\begin{tabular}{|c|c|c|c|}
\hline Province & $\mathbf{2 0 1 0}$ & $\mathbf{2 0 1 5}$ & $\mathbf{2 0 2 0}$ \\
\hline Jawa Barat & 43.227 & 46.710 & 49.936 \\
\hline Jawa Timur & 37.566 & 38.848 & 39.886 \\
\hline Jawa Tengah & 32.444 & 33.774 & 34.940 \\
\hline Sumatera Utara & 13.029 & 13.938 & 14.704 \\
\hline Banten & 10.689 & 11.955 & 13.161 \\
\hline DKI Jakarta & 9.640 & 10.178 & 10.645 \\
\hline
\end{tabular}

Table 2:- Projection Table of the Highest Population by Province in 2010 - 2020

(In a Thousand Souls)

Source: BPS Central Java Province (2020)

The development paradigm in a country can be measured and seen through the quality of life of the people as reflected in the Human Development Index (HDI). Increasing quality human resources is one of the efforts to increase economic growth apart from increasing capital. The more productive population will have an effect on the number of labor force participation rates available so that it can increase the production capacity of goods and services and reduce the unemployment rate (Todaro, 2004). The Human Development Index is an important indicator that can be used to measure the quality of the results of economic development, namely the degree of human development in Tambunan (2003). Based on Table 3 below, it can be seen that the human development index in Central Java Province during 2011 to 2018 was always below the national index.

\begin{tabular}{|c|c|c|}
\hline Year & Central Java & Indonesia \\
\hline 2011 & 66,64 & 67,09 \\
\hline 2012 & 67,21 & 67,70 \\
\hline 2013 & 68,02 & 68,31 \\
\hline 2014 & 68,78 & 68,90 \\
\hline 2015 & 69,49 & 69,55 \\
\hline 2016 & 69,98 & 70,18 \\
\hline 2017 & 70,52 & 70,81 \\
\hline 2018 & 71,12 & 71,39 \\
\hline
\end{tabular}

Table 3:- Table of Human Development Index in Central Java Province 2011-2018

Source: BPS Central Java Province (2020)

Economic growth that occurs in an area can be observed through how much workforce there are in an area. This is reflected in the percentage of the labor force participation rate. Sukirno (2004) states that the labor force participation rate is defined as the ratio between the number of workers and the people who have entered the working age in a certain time period and area. The theory of economic growth which discusses labor is the neo-classical Solow-Swan theory which states that in the end economic conditions will depend, one of which, on labor growth in addition to the use of technology. Based on Table 5 below, it can be seen that the percentage of the labor force participation rate in Central Java Province always increases every year and is above the percentage nationally. However, every year the percentage of the labor force tends to decline.

\begin{tabular}{|c|c|c|}
\hline Year & Central Java & Indonesia \\
\hline 2011 & $70.15 \%$ & $66,78 \%$ \\
\hline 2012 & $71.26 \%$ & $67,76 \%$ \\
\hline 2013 & $70.43 \%$ & $66,77 \%$ \\
\hline 2014 & $69.68 \%$ & $66,60 \%$ \\
\hline 2015 & $67.86 \%$ & $65,76 \%$ \\
\hline 2016 & $67,15 \%$ & $66,34 \%$ \\
\hline 2017 & $69.11 \%$ & $66,67 \%$ \\
\hline 2018 & $68.56 \%$ & $67,26 \%$ \\
\hline
\end{tabular}

Table 4:- Table of Percentage of Labor Force Participation Rate in Central Java and Indonesia 2011-2018 Source: BPS Central Java Province (2020)

This research was conducted using dynamic panel regression because in fact some of the economic variables used have dynamic characteristics. The use of data regression with dynamic panels is carried out by adding the lag of the dependent variable in the previous year to serve as an independent variable. The use of Ordinary Least Square (OLS) estimation will produce biased and inconsistent estimates because the lag of the dependent variable has a correlation with the error between the independent variables. The Generalize Method of Moment Arrelando-Bond is used to solve this problem. 
Bontems (2002) states that the advantage of the Generalize Method of Moment Arrelando-Bond is that the estimates obtained from research data will be more complex and detailed. In addition, according to him, the uncertainty of the data parameters used can be resolved using this method. Other advantages of GMM-AB according to Baltagi (2005) include controllable heterogeneity in individuals, more, varied and efficient information provided, and being able to explain and identify more simply the research data used.

The results obtained from the use of GMM-AB are obtained by an econometric model that includes the economic variables used, including the level of savings, population, human development index, and labor force participation rate. This will later describe the conditions of economic growth and determine the elasticity of the impact both in the short and long term in Central Java Province with the observation period of 2011-2019.

\section{LITERATURE REVIEW}

\section{A. Economic Growth Theory}

There are several theories regarding economic growth, namely views according to classical economics and neoclassical economics. According to Smith (in Arsyad, 2010), there are three factors that influence classical economic growth including: 1.) available natural resources, 2.) number of people or population, 3.) amount of capital or stock of goods. Robert Solow and Trevor Swan are experts from a neo-classical view of economics. The theory of neoclassical economic growth originates from the understanding that economic growth is characterized by the addition or development of several aggregate supply factors.

This theory also emphasizes that production factors and technological progress are the determining factors for economic growth in Sukirno (2004). Boediono (2005) adds that Robert Solow's neo-classical economic model is one form of the development of classical economic theory, the neo-classical economy proposed by Robert Solow if it is formed more formally can be described as follows: $\mathrm{Y}=\mathrm{TKaLt} 1-\mathrm{a}$

Where $\mathrm{Y}$ is the output produced, while $\mathrm{K}$ is the capital owned, $\mathrm{L}$ is labor, and $\mathrm{T}$ is the level of technological progress used. The level of technological development in the production function is considered an exogenous factor. The main assumption of Solow's economic theory is that capital in the future will experience diminishing returns. This situation is characterized by a steady supply of labor which will have an impact on capital accumulation on the resulting output to be less (Mankiw, 2006).

\section{B. Savings Rate}

According to Nopirin (2012) savings are defined as deposits whose withdrawal system can be done with certain agreed conditions. Kasmir (2008) savings deposits can be made at any time or at any time where the withdrawal of funds does not require a maturity condition such as when a deposit is withdrawn. According to Keynes (in Jhingan, 2010) people in general have a certain tendency to save which is used as a function of income. Robert Solow's theory is a theory that underlies saving is used as a factor in economic growth. According to Solow, a high saving rate will only temporarily increase economic growth until the economy reaches a state when the new steady state is higher than before.

Sukirno (2011) states that investment is defined as a form of shopping or expenditures from various types of businesses for the need to purchase capital goods or other supplements with the aim of increasing production capacity. Furthermore, according to Todaro (2004), investment has an important role in the movement of the nation's economy. This is because the investment will form a large capital so that the production capacity is also large. Large investments will make national income increase and create new jobs so that it can reduce the level of poverty in a country. Investment itself is divided into two types, namely PMDN (Domestic Investment) and PMA (Foreign Investment). The difference between the two is from the source of the investment obtained, which comes from within or outside the country in a certain time period.

Nowadays, the central government is increasingly active in offering investments both from within and from foreign countries in Indonesia. There are two types of laws that regulate these two investments, namely Law No.1 of 1967 concerning foreign investment and enhanced by Law No.11 of 1970. Furthermore, domestic investment or PMDN is regulated by Law No.6 of 1968 which is equipped with by Law No.12 of 1970 .

\section{Total population}

Population is defined as all people who have a domicile or place of residence in a geographic area for at least 6 months or more or they are domiciled for a period of less than 6 months but with the aim of settling in the area (Badan Pusat Statistik, 2018). Adam Smith in Siskawati (2014) states that high population growth in an area will result in an increase in output and market expansion both from within and outside the country. Hasanur (2016) Increasing population is a positive thing and not a problem because it is considered an important element that can trigger economic growth and development. The amount of income will have an effect on the population, if the population has increased, the income to be received will also increase.

The population growth that occurs in a country according to Adam Smith in Jhingan (2010) can trigger the acceleration of the industrialization process. Population growth is one of the increasing economic factors because the capital owned is already abundant so that the prosperity obtained is also high. The theory of neo-classical economic growth shows the relationship between the availability of population in a country and economic growth. The theory of economic growth emphasizes that the population factor plays a major role in influencing a country's aggregate economy. If the consumption of a large proportion of the 
population is high, the economy will also grow, which can be reflected in the country's economic growth rate.

\section{Human Development Index}

Saputra (2011) states that the human development index is defined as a measurement tool for the achievement of human development based on several basic components of quality of life. Asnidar (2018) adds that HDI can be used to classify the development of a country and distinguish between developed, developing, and underdeveloped countries. The level of success of human development can be seen from the size of the services provided by the government to the people of Haryadi (2016). The Central Bureau of Statistics (2020) states that the human development index is divided into three, including: 1.) Length of life, can be measured using life expectancy 2.) Education level, can be measured using length of schooling and literacy rates, and 3.) The level of feasibility of life as measured by the ability in the form of per capita expenditure which is adjusted to the applicable currency.

Asnidar (2018) adds that the human development index is usually used to determine the level or extent of the quality of life of the community and determine the level of development success in an area. Mirza (2012) in his research states that an increase in economic growth marked by an increase in quality human capital is believed to be able to improve the economic performance of people in an area. Robert Solow said that labor, capital and technology have a big influence on the level of economic growth of a country.

\section{E. Labor Force Participation Rate}

Based on Law Number 13 of 2003, labor is defined as the ability to do work with the aim of producing the production of goods or services that are used to meet their own needs which can be done by everyone. The minimum age limit for a person to be included in the working age according to the Labor Force Survey (SAKERNAS) is 15 years. The working age limit is in accordance with the provisions made by the International Labor Organization (ILO).

Nainggolan and Indra (2009) there are several concepts regarding employment, including: 1.) Labor, which is defined as residents who have aged 15 years and over who are able to produce goods or services, 2.) The workforce, including part of the workforce which is defined as residents whose main activity is working during the week and who are looking for work, 3.) Non-workforce, residents who are 15 years old or more but whose main activity is not working such as taking care of the household or going to school, and 4.) Level of participation labor force, is the ratio between the number of workers and the labor force available in a certain area and at a certain time.

The Central Bureau of Statistics (2012) states that the labor force participation rate is defined as the ratio between the working age population in the labor market, who are either working or looking for work so as to provide supplies to workers in managing natural products that are already available. Sukirno (2004) states that the labor force participation rate is defined as a comparison between the number of workers and the number of people who have entered working age in a certain period of time. Then according to Mulyadi (2003) the level of labor force participation also explains the large number of people who are said to be the labor force in a certain time set with the aim of comparing these age groups.

\section{F. Framework}

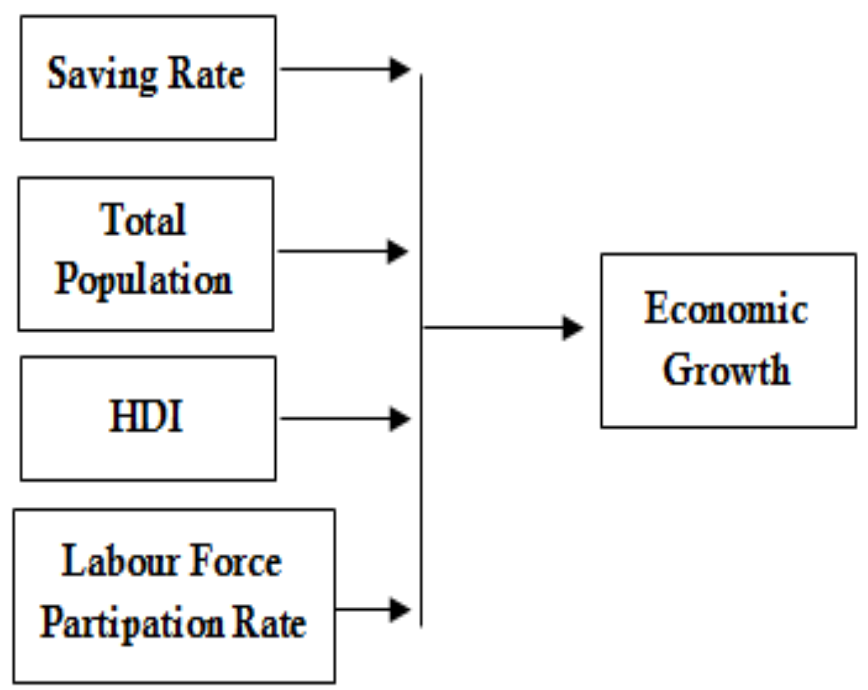

Fig 2:- Framework

\section{RESEARCH METHODOLOGY}

This type of research is descriptive quantitative in which the data used in this study are secondary data obtained from the Central Bureau of Statistics. These data include independent variables (savings rate, population, human development index, and labor force participation rate). Then for the dependent variable data, namely economic growth in Central Java Province in 2011 to 2018. The population of this study were 35 districts and cities in Central Java Province with the observation year 2011-2018 so that the number of samples in this study was 315 samples with the quota sampling technique. This research was conducted using dynamic panel regression analysis Generalized Method of Moment Arrelano Bond using Stata software.

\section{RESULTS}

This research was conducted with two steps of data analysis including the first through simultaneous testing using Ordinary Least Square (OLS). Furthermore, for the second step, namely by conducting an analysis using the Generalized Method of Moment Arrelano Bond. 


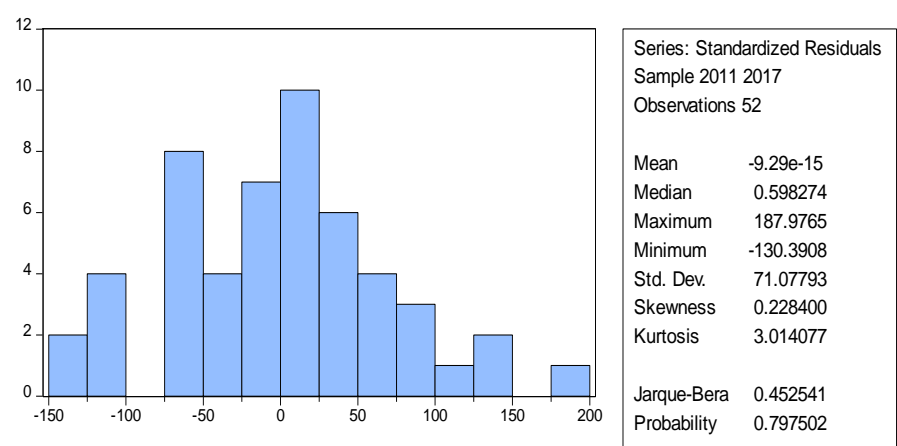

Fig 3:- Normality Test

Source: Processed by Author (2020)

The probability value in Figure 2 above shows a value of 0.79 , which means that the data used is data that is normally distributed because it has a value greater than
0.05 . The multicolonierity test results can be seen in the table below:

\begin{tabular}{|c|c|c|c|c|}
\hline & IPM & TPAK & JP & TAB \\
\hline IPM & 1.000000 & 0.666447 & 0.408311 & 0.704513 \\
\hline TPAK & 0.666447 & 1.000000 & 0.350589 & 0.761873 \\
\hline JP & 0.408311 & 0.350589 & 1.000000 & 0.127450 \\
\hline TAB & 0.704513 & 0.761873 & 0.127450 & 1.000000 \\
\hline
\end{tabular}

Table 5:- Multikolonierity Test

Source: Processed by Author (2020)

The value based on Table 6 above shows that none of the independent variables is above 0.8. This means that all the independent variables used in this study are free from multicollinearity symptoms.

\begin{tabular}{|c|c|c|c|c|}
\hline Variable & Coefficient & Std. Error & t-Statistic & Prob. \\
\hline IPM & $2.06 \mathrm{E}+09$ & $1.31 \mathrm{E}+09$ & 1.572765 & 0.1225 \\
\hline TPAK & -0.000192 & 0.000179 & -1.076214 & 0.2873 \\
\hline JP & $-1.35 \mathrm{E}-05$ & $1.37 \mathrm{E}-05$ & -0.982864 & 0.3307 \\
\hline TAB & -102634.4 & 59433.42 & -1.726880 & 0.0908 \\
\hline C & 103.4758 & 49.13083 & 2.106127 & 0.0406 \\
\hline R-squared & 0.209745 & Mean dependent var & 56.24959 \\
\hline Adjusted R-squared & 0.142489 & S.D. dependent var & 49.04308 \\
\hline S.E. of regression & 45.41481 & Akaike info criterion & 10.56077 \\
\hline Sum squared resid & 96937.74 & Schwarz criterion & 10.74838 \\
\hline Log likelihood & -269.5799 & Hannan-Quinn criter. & 10.63269 \\
\hline F-statistic & 3.118620 & Durbin-Watson stat & 1.468971 \\
\hline Prob(F-statistic) & 0.023470 & \multicolumn{2}{c|}{} \\
\hline
\end{tabular}

Tabel 6:- Heterokedastisity Test

Source: Processed by Author (2020)

The probability based on Table 7 above shows that all independent variables on the absolute residual variables used in the study have a value above 0.05 , meaning that all variables are free from heteroscedasticity. The following is the Estimation Result of Ordinary Least Square (OLS):

\begin{tabular}{|c|c|c|c|c|c|}
\hline Predictor & Coefisien & $\begin{array}{c}\text { Standart } \\
\text { Eror }\end{array}$ & \multicolumn{2}{|c|}{ P-value } \\
\hline$\delta P E_{i, t-1}$ & 0.2642956 & 0.0622618 & 4.24 & 0.000 \\
\hline$I P M_{i, t}$ & $-8.87 \mathrm{e}+08$ & $6.41 \mathrm{e}+08$ & 1.38 & 0.169 \\
\hline$T P A K_{i, t}$ & $-8.79 \mathrm{e}-07$ & 0.0000797 & 0.01 & 0.991 \\
\hline$J P_{i, t}$ & 0.0000178 & 0.0000167 & 1.06 & 0.289 \\
\hline$T A B_{i, t}$ & -19066.5 & 39903.11 & 0.48 & 0.633 \\
\hline$\beta_{0}$ & 152.0616 & 38.70655 & 3.93 & 0.000 \\
\hline & $\mathbf{R}^{2}=\mathbf{0 . 1 8 6 7}$ & \multicolumn{3}{|c|}{ Prob (F-statistic) $=0.0000$} \\
\hline
\end{tabular}

Table 7:- Estimation Results of Ordinary Least Square (OLS)

Source: Processed by Author (2020)

The F statistical probability value is 0.0000 with a significance level in this study of 0.05 or 5 percent. This means that there is a simultaneous significant influence on the independent variable in explaining the dependent variable. Then the R-Square value shows a number of 0.1867 indicating that the effect of the independent variable in explaining the dependent variable is 18.67 percent. This percentage is quite low partially but if seen simultaneously is significant. The coefficient value for the dependent variable on economic growth at lag 1 is 0.264 or a value less than 1 so that the estimation to find the coefficient is consistent. Because the partial test on the Ordinary Least Square (OLS) above is quite low, it is necessary to carry out further tests through partial tests using the GMM-AB

\begin{tabular}{|c|c|c|c|c|}
\hline Prediktor & Koefisien & $\begin{array}{c}\text { Standard } \\
\text { Eror }\end{array}$ & $\mathbf{Z}$ & $\begin{array}{c}\text { P- } \\
\text { value }\end{array}$ \\
\hline$\delta P E_{i, t-1}$ & -0.2597689 & 0.1057989 & -2.46 & 0.014 \\
\hline$I P M_{i, t}$ & $1.48 \mathrm{e}+09$ & $4.69 \mathrm{e}+09$ & 0.32 & 0.753 \\
\hline$T P A K_{i, t}$ & 0.0003685 & 0.0001783 & 2.07 & 0.039 \\
\hline$J P_{i, t}$ & -0.0008037 & 0.0005059 & -1.59 & 0.112 \\
\hline$T A B_{i, t}$ & -345985.7 & 196872.6 & -1.76 & 0.079 \\
\hline
\end{tabular}

Table 8:- Partial Test Results Generalized Method of Moment

Source: Processed by Author (2020)

The $\mathrm{p}$-value on the independent variables includes HDI of 0.753 , TPAK 0.039 , population of 0.112 , and a savings rate of 0.079 . Thus, partially the independent variable that has a significant positive effect on the dependent variable is only found in the TPAK variable or the level of labor force participation because it has a value 
below 0.05 and a coefficient of 0.00 . This shows that the predictor model in this study can be used.

\begin{tabular}{|c|c|c|}
\hline Order & $\mathbf{Z}$ & Prob \\
\hline 1 & -2.9879 & 0.0028 \\
\hline 2 & -1.4148 & 0.1571 \\
\hline
\end{tabular}

Table 9:- Arellano-Bond Test Results

Source: Processed by Author (2020)

The Arrelano-Bond test results show that the use of the dynamic panel method with this approach has met several criteria for the best model, namely consistency and the instrument variables used are valid. The results on Arrelano Bond $(\mathrm{AB})$ on order 1 show a probability value of 0.0028 and order 2 of 0.1571 .

\begin{tabular}{|c|c|c|}
\hline \multirow{2}{*}{ Sargan Test } & Chi2(5) & $\mathbf{2 2 . 3 5 0 6 7}$ \\
\cline { 2 - 3 } & Prob $>$ chi 2 & 0.0004 \\
\hline
\end{tabular}

Table 10:- Sargan Test Results

Source: Processed by Author (2020)

The probability value in Table 8 above shows a value of 0.05 with an alpha $\alpha$ level of 5 percent. This shows that the estimates used in this study can be said to be consistent and there is no autocorrelation in the first order difference error. The following are the results of the GMM-AB test:

\begin{tabular}{|c|c|c|c|c|}
\hline Predictor & Coefisien & \multirow{2}{*}{$\begin{array}{c}\text { P- } \\
\text { value }\end{array}$} & & \multicolumn{2}{|c|}{$\begin{array}{c}\text { Ehort } \\
\text { Term }\end{array}$} & $\begin{array}{c}\text { Long } \\
\text { Term }\end{array}$ \\
\hline$\delta P E_{i, t-1}$ & - & 0.015 & & \\
& & - & & \\
\hline$I P M_{i, t}$ & $1.48 \mathrm{e}+09$ & 0.754 & $-7.77 \mathrm{e}+09$ & $1.07 \mathrm{e}+10$ \\
\hline$T P A K_{i, t}$ & 0.0003685 & 0.040 & 0.0000172 & 0.0007199 \\
\hline$J P_{i, t}$ & - & 0.114 & - & 0.0001932 \\
& 0.0008037 & & 0.0018007 & \\
\hline$T A B_{i, t}$ & -345985.7 & 0.081 & -733986.7 & 42015.39 \\
\hline$\beta_{0}$ & 1069.04 & 0.079 & & \\
\hline
\end{tabular}

Table 11:- Generalized Method of Moment Arellano-Bond (GMM-AB) Test Results

Source: Processed by Author (2020)

Based on Table 12 above, the lag coefficient of economic growth p-value has a value below 0.05 and a negative coefficient means that economic growth in the previous year has a significant effect and is negatively related to economic growth in the period in this study. In table 12 above, it can also be seen that the relationship of each independent variable to the dependent variable. The variables of saving rate and population have a negative and insignificant effect on economic growth. Meanwhile, the HDI variable has an insignificant positive effect and TPAK has a significant positive effect on economic growth.

In addition to the influence of the independent variables on the dependent variable, GMM-AB also knows about short and long term elasticity. Based on Table 12 above, it can be seen that the human development index variable has an influence on economic growth where every 1 percent increase in HDI will reduce the rate of economic growth by 0.000017 percent in the short term and increase 0.00071 in the long term. Furthermore, the TPAK variable has an influence on economic growth where every 1 percent increase in TPAK will increase the rate of economic growth both in the short and long term with elasticities of 0.000017 and 0.000719 , respectively.

Then the population number variable has an influence on the rate of economic growth where every 1 percent increase in the population will decrease the economic growth rate by 0.00018 in the short term and increase 0.00019 in the long term. Furthermore, the latter is the savings rate variable where every 1 percent increase in economic growth will reduce economic growth in the short term by 733986.7 and increase economic growth in the long term by 42014.39 .

The analysis used in this study is the Generalized Method of Moment Arrelano Bond (GMM-AB). The use of the GMM-AB method is carried out because some of the variables in this study have a dynamic character, meaning that they always change every year. The results in this study indicate that simultaneously the independent variables used, namely the savings rate, population, human development index, and labor force participation rate have an effect on the dependent variable, namely economic growth in Central Java Province. However, this study also shows that the influence of the independent variable in partially explaining the dependent variable is still quite low, namely 18.67 percent, so that other variables are needed that can be used to explain economic growth in Central Java Province.

\section{A. The Effect of Savings Rate on Economic Growth}

Based on the results of testing using the Generalized Method of Moment Arrelano Bond (GMM-AB), it shows that there is an insignificant negative effect between the two. The relationship between the saving rate and economic growth is negative and insignificant according to research by Indra and Dita (2016). This is due to the fact that the income of most people in Central Java Province is still quite low, so the interest rate received is also small. This is one of the reasons why people tend to save quite low. In addition, according to Jhingan (2010), the saving rate can be a bad thing because an excess in the saving rate will have an impact on reducing aggregate demand which causes the production of goods and services to decrease. The reduced level of production of goods and services will cause producer incomes and economic growth to decline.

In addition to knowing the relationship between the savings rate variable on economic growth, the GMM-AB method also knows the elasticity in the short and long term between each variable. The results in this study indicate that in the short term the saving rate has a negative effect on economic growth because high capital in the short term is unable to increase economic growth so that the impact will only be felt in the long term. The benefits of saving or capital will be felt in the long term because the higher the savings rate in the long term, the higher the interest you will get. 
Based on the results of the research above, it can be seen that the savings rate variable has an insignificant negative relationship to economic growth in Central Java Province in the period 2011 to 2018. This is in accordance with the theory of Keynes in Jhingan (2010) which states that savings can be appropriate bad because there is an excess of saving which causes a decrease in aggregate demand, which results in a decrease in the rate of economic growth.

\section{B. The Effect of Total Population on Economic Growth}

The results of this study indicate that the population has a significant positive effect on economic growth. The relationship between total population and negative economic growth is insignificant because if the population in a country increases, the opportunity to get a job becomes smaller so that people become more unproductive and can reduce economic growth. This is consistent with research by Purwaningsih (2011) which states that population has a negative effect on economic growth.

Then, when viewed from the elasticity in the short term, there is a negative effect between population size and economic growth. Meanwhile, in the long term, it has a positive effect. This is because in the long term, the increase in population will be more controllable by the government than in the short term. For example, various government programs can be realized if they are carefully planned and carried out in a long and sustainable manner.

Based on the results of the research above, it can be seen that there is a significant negative effect between the population size variable on economic growth in Central Java Province from 2011 to 2018. This effect is in accordance with the theory by Malthus in Purwaningsih (2011) which states that in the initial conditions the population a high rate can affect the economic growth of a region, but at an optimum condition, population growth will actually result in a decrease in economic growth.

\section{The Effect of the Human Development Index on Economic Growth}

Based on the results of this study, it is stated that there is a significant positive relationship between the human development index and economic growth. The positive and insignificant relationship between the human development index and economic growth in this study is because if the value of the human development index is high it indicates that the indices in it such as health, education, and others are also high so that the effect on economic growth will increase. For example, one part of the human development index is the level of education. The higher the level of education of the community in an area will cause the ability and skills of the community to also increase and affect the ability to produce goods and services. If the goods and services produced by the community increase, it will be able to encourage the joints of the economy so that economic growth will increase.

Then when viewed from the short and long term elasticity, there is a difference in elasticity where in the short term it has a negative effect while in the long term it has a positive effect. This is because in the short term the relationship between the human development index has not had a major impact on economic growth, it can even have a negative effect than in the long term. For example, if the percentage of economic growth that rises in a country is not qualified, it means that only relying on the consumption sector will have a negative impact on the human development index so that it can decrease.

Based on the research results above, it shows that there is an insignificant positive influence between the human development index variable and the level of economic growth in Central Java Province from 2011 to 2018. This is in accordance with the theory of neo-classical economic growth by Robert Solow where one of the main production factors in shaping economic growth is labor. The human development index itself is used to describe the extent to which human development indications can run well. If the value of the human development index is high, it shows that the measure of the quality of the workforce which consists of education, health, and life expectancy is also good.

\section{The Effect of Labor Force Participation Rate on Economic Growth}

Based on the results of this study, it is stated that the relationship between the level of labor force participation and economic growth is a significant positive. A significant positive relationship between the level of labor force participation and economic growth is caused because if the percentage of the labor force participation rate is high, it indicates that the population or community is working more so that unemployment is reduced. The increasing number of people working indicates that society is becoming more productive and the opportunity to produce goods or services increases. This situation makes there is an increase in economic growth in a country or region.

Then when viewed from the elasticity in the short and long term, the variable of labor force participation rate is the only variable that has a significant positive effect. This shows that if there is an increase in the level of labor force participation, economic growth will also increase both in the short term and in the long term. The elasticity value is higher in the long term of 0.000719 compared to the short term of 0.000017 .

Based on the results of the research above, it shows that there is a significant positive relationship between the variable rate of labor force participation and economic growth in Central Java Province from 2011 to 2018. This is in accordance with Robert Solow's theory of economic growth, which states that one of the main factors shaping economic growth is energy. work. The labor force participation rate variable shows the percentage of the large number of the population at working age who have worked so that the population is more productive and reduces the unemployment rate. This of course will have implications for the betterment of the economy so that economic growth can also increase. 


\section{CONCLUSION}

Based on the results of the data analysis and discussion described above, it can be concluded that simultaneously economic growth in Central Java Province is influenced by several variables, namely the level of savings, population, human development index, and labor force participation rate.

$>$ The saving rate has an insignificant negative effect on economic growth in Central Java Province from 2011 to 2018. These results can provide a reference that the excess in the saving rate will have an impact on reducing aggregate demand which causes the production of goods and services to decrease so that producer income and growth the economy is also down. The elasticity in the short term between the saving rate and economic growth is negatively related while in the long run it is positively.

$>$ The population has an insignificant negative effect on economic growth in Central Java Province from 2011 to 2018. These results can provide a reference that the population in an area increases, the opportunity to get a job is getting smaller and unemployment increases so that it can reduce economic growth. The elasticity in the short term between total population and economic growth is negatively related while in the long run it is positively.

$>$ The human development index has an insignificant positive effect on economic growth in Central Java Province from 2011 to 2018. These results can provide a reference that the value of the human development index in a region is high, indicating that the index of services such as health education and others is high so that economic growth also follows. ride. The elasticity in the short term between total population and economic growth is negatively related while in the long run it is positively.

The labor force participation rate has a significant positive effect on economic growth in Central Java Province from 2011 to 2018. These results can provide a reference that the percentage of the high labor force participation rate indicates that more people work and become productive so that unemployment decreases. The reduction in the unemployment rate shows that the opportunity to produce goods and services in the area is getting bigger so that it can increase the rate of economic growth. The elasticity in the short and long term between the labor force participation rate and economic growth shows an equally positive value.

The limitation in this study is that the variables used are only four variables in which simultaneously it has a significant effect, but partially the influence between independent variables in explaining the dependent variable is still quite low, namely 18.67 percent. The results of this study can provide suggestions that local governments should maximize high savings rates to move the joints of the economy to produce more goods and alone, among others, can be done by making several development programs that can be felt directly or indirectly for the benefit of the wider community.
The Central Java Provincial Government should make a breakthrough in the form of policies to improve the welfare of the community as stated in the Regional Medium Term Development Plan (RPJMD). This policy is necessary so that although the population in Central Java Province is quite high, if the level of welfare is high, it will have a major impact on the welfare of the community as reflected in the human development index. In general, the labor force participation rate in Central Java Province is quite good because it has increased every year. However, the Central Java provincial government should start making policies such as training or development of workforce skills. This is because the percentage of the labor force participation rate from 2011 to 2018 tends to show a decreasing trend every year.

\section{REFERENCES}

[1]. Arsyad. 2010. Ekonomi Pembangunan: Edisi Ketiga. Yogyakarta: STIE YKPN.

[2]. Asnidar, A. 2018. Pengaruh Indeks Pembangunan Manusia dan Inflasi Terhadap Pertumbuhan Ekonomi di Kabupaten Aceh Timur. Jurnal Samudera Ekonomika, Vol 2 No.1.

[3]. Baltagi, B. H. 2005. Economic Analysis of Panel Data Third Edition. England. British Library Cataloguing Publication Data.

[4]. Boediono. 2005. Ekonomi Mikro. Yogyakarta: BPFE Universitas Gadjah Mada.

[5]. Bontems, dkk. 2002. Testing Normality GMM Approach. Montreal: Scientificts Series.

[6]. Dita dan Indra. 2016. Pengaruh Tabungan, Pengeluaran Pemerintah, dan Investasi Swasta Terhadap Produk Domestik Bruto di Indonesia. Jurnal Ekonomi Qu (Jurnal Ilmu Ekonomi), Vol.6 No.2 Oktober 2016.

[7]. Harliyani dan Haryadi 2016. Pengaruh Kinerja Keuangan Pemerintah Daerah Terhadap Indeks Pembangunan Manusia di Provinsi Jambi. Jurnal Perspektif Pembiayaan dan Pembangunan Daerah.

[8]. Hasanur, D. 2016. Pengaruh Jumlah Penduduk dan Pertumbuhan Ekonomi Terhadap Pendapatan Asli Daerah (Studi Kasus di Kabupaten/Kota Provinsi Aceh. Skripsi. Aceh: Universitas Teuku Umar Meulaboh.

[9]. Hendarto. 2012. Analisis Pengaruh Aglomerasi, Tenaga Kerja, Jumlah Penduduk, dan Modal Terhadap Pertumbuhan Ekonomi Kabupaten Kendal. Diponegoro Journal Of Economics, Vol.1 No.1, 1:16.

[10]. Jhingan, M. 2000. Ekonomi Pembangunan dan Perencanaan. Jakarta: PT. Raja Grafindo. Kasmir. 2008. Bank dan Lembaga Keuangan Lainnya Edisi Revisi. Jakarta: PT. Raja Grafindo Persada.

[11]. Mankiw, G. 2006. Principle of Economics: Pengantar Ekonomi Makro Edisi Ketiga. Jakarta: Salemba Empat. 
[12]. Mirza. 2012. Pengaruh Kemiskinan, Pertumbuhan Ekonomi, dan Belanja Modal Daerah Terhadap Indeks Pembangunan Manusia di Jawa Tengah Tahun 20062009. Jurnal Ekonomi dan Studi Pembangunan, Vol. 1 (1) 2012.

[13]. Muana, N. 2001. Makro Ekonomi, Teori, Masalah, dan Kebijakan. Jakarta: PT. Perdana.

[14]. Mulyadi. 2003. Ekonomi Sumberdaya Manusia Dalam Perspektif Pembangunan Edisi Kesatu. Jakarta: Kesatu.

[15]. Nainggolan dan Indra. 2009. Analisis Faktor-Faktor yang Mempengaruhi Kesempatan Kerja di Kabupaten/Kota Provinsi Sumatera Utara. Tesis. Medan: Sekolah Pascasarjana Universitas Sumatera Utara.

[16]. Nopirin. 2012. Pengantar Ilmu Ekonomi Mikro dan Makro. Yogyakarta: BPFE.

[17]. Purwaningsih. 2011. Analisis Identifikasi FaktorFaktor yang Mempengaruhi Tingkat Ketahanan pangan Rumah Tangga di Provinsi Jawa Tengah Tahun 2009. Jurnal Ilmu Ekonomi dan Pembangunan FE UNS Surakarta, Vol.11 Nomor 1 Tahun 2011.

[18]. Rochaida, E. 2016. Dampak Pertumbuhan Penduduk Terhadap Pertumbuhan Ekonomi dan Keluarga Sejahtera di Provnsi Kalimantan Timur. Forum Ekonomi Fakultas Ekonomi dan Bisnis Universitas Mulawarman, Volume 18 No.1 2016.

[19]. Saputra, W. 2011. Analisis Tingkat Pertumbuhan Ekonomi dan Potensi Ekonomi Produk Domestik Regional Bruto Kabupaten Pati Tahun 2002-2005. Jurnal Ekonomi Pembangunan Fakultas Ekonomi Universitas Semarang, Vol.1, 1-8.

[20]. Suhel, M. 2015. Analisis Kausalitas Antara Tabungan Masyarakat Dengan Pertumbuhan Ekonomi di Kota Palembang Tahun 1995-2013. Jurnal Ekonomi Pembangunan. Hal: 86-95.

[21]. Siskawati, N. 2014. Pengaruh Jumlah Penduduk dan Pertumbuhan Ekonomi Terhadap Pendapatan Asli Daerah Antar Kabupaten/Kota di Provinsi Riau. Jurnal Paradigma Ekonomi, Volume 9 No.2.

[22]. Sodik, J. 2007. Investasi dan Pertumbuhan Ekonomi Regional. Jurnal Ekonomi Pembangunan, Volume 10 (2), 157-170.

[23]. Sukirno, S. 2011. Makroekonomi Teori Pengantar Edisi Ketiga. Jakarta: Rajawali Pers.

Tambunan, T. 2003. Ekonomi Regional Teori dan Aplikasi. Jakarta: PT. Bumi Aksara.

[24]. Todaro dan Smith. 2004. Pembangunan Ekonomi di Dunia Ketiga. Jakarta: Erlangga. 